\author{
María Inés Nin Márquez* \\ ORCID: 0000-0003-2635-8169 \\ Buenos Aires, Argentyna \\ Carina Rossa** \\ ORCID: 0000-0001-7290-0217 \\ Watykan
}

\title{
Wychowanie interpersonalne
}

\section{Interpersonal Education}

Summary: Recent contributions from neuroscience and their implications on school teaching have encouraged openness to new knowledge, to the need for new skills and to the revamping of teaching, placing educational relationship at the centre of everything. The brain has been designed to learn through sharing experiences. The purpose of these pages is hence to see if there is a correlation between mental development and relationality. In that sense, as Chiara Lubich's pedagogy highlights, educational goal is to develop personal identity starting from the encounter with the other. Besides, interpersonal relationships and emotions will help to improve learn-

* Prof. María Inés Nin Márquez PhD, dr nauk medycznych, specjalista w naukach o żywieniu, postracjonalnej terapii poznawczej, konsultant, professor na Universidad Abierta Interamericana (UAI) w Buenos Aires. Adres: Ciudad de Buenos Aires AR, Av. San Juan 951, C1147 AAH; e-mail: inesnin25@gmail.com.

** Carina Rossa PhD, absolwentka psychopedagogiki na Universidad Catolica Argentina, doktor w dziedzinie psychopatologii rozwoju i transformacji społecznej w Libera Università Maria Santissima Assunta (LUMSA) w Rzymie; koordynatorka Papieskiej Fundacji Scholas Occurrentes. Adres: Città del Vaticano, Piazza San Calisto 16; e-mail: carina.rossa@scholasoccurrentes.org. 
ing. Neuroscience and cognitive neuroscience have demonstrated there is an interconnection between perception, emotion and cognition during school learning. Therefore, we think that valuation of relational and emotional dimensions in education can improve the processes of teaching and learning. In fact, in the last decades, studies and research about human brain function and teaching and learning processes have led to new findings that nowadays are modifying current pedagogy. The progress on science says that interpersonal skills development can improve children's brain development. The relationship with others and other attachment figures is the enabler to allow or inhibit the organisation of neuronal connections, the capability to activate them as a response to stimulus and allow the expression of brain structures genetically determined. This scenario presents the development of prosocial behaviour, which optimise and postulate the capacity for empathy, promoted by Chiara Lubich as behavioural categories of the Art of Love.

Keywords: education; interpersonal neurobiology; brain plasticity; mirror neurons; prosocial behaviours.

Streszczenie: Ostatnie artykuły z zakresu neuronauk oraz ich wpływu na dydaktykę uzasadniają otwarcie się na nowe elementy wiedzy, na konieczność opanowania nowych umiejętności i potrzebę odnowienia samej dydaktyki przez usytuowanie w centrum wszystkiego relacji wychowawczej. Mózg ludzki został tak zaprojektowany, aby uczyć się poprzez dzielenie się doświadczeniami. Celem niniejszego artykułu jest zweryfikowanie istnienia korelacji pomiędzy rozwojem umysłowym a relacyjnością. Podejście pedagogiczne Chiary Lubich, wpisujące się w ten kierunek zainteresowań, podkreśla, że celem procesu wychowawczego jest rozwój tożsamości osobistej, zapoczątkowany spotkaniem z drugim. Ponadto jej zdaniem zarówno relacje interpersonalne, jak i emocje pomagają osiągnąć lepsze wyniki uczenia się. Neuronauki i nauki kognitywne wykazały wzajemne powiązania pomiędzy percepcją, emocjami i poznaniem w nauczaniu szkolnym. Uważa się zatem, że wzmocnienie wymiarów relacyjnych i emocjonalnych $\mathrm{w}$ dydaktyce może poprawić procesy nauczania i uczenia się. Rzeczywiście, w ostatnich dziesięcioleciach badania naukowe nad funkcjonowaniem ludzkiego mózgu i procesami uczenia się doprowadziły do nowych odkryć, które modyfikują aktualną wiedzę edukacyjną. Postępy nauki potwierdzają fakt, że rozwój umiejętności interpersonalnych może poprawić rozwój mózgu dzieci. To właśnie stosunek do innych osób - także tych, które biorą odpowiedzialność za dzieci - rozwija lub hamuje organizację obwodów neuronalnych i zdolność do aktywacji w odpowiedzi na bodźce oraz umożliwia ekspresję określonych genetycznie struktur mózgu. W niniejszej pracy przedstawiony jest rozwój zachowań prospołecznych, 
które optymalizują i domagają się zdolności do empatii, promowanych przez Chiarę Lubich jako kategorii behawioralnych Sztuki miłowania.

Slowa kluczowe: wychowanie; neurobiologia interpersonalna; plastyczność neuronalna; neurony lustrzane; prospołeczność.

Chiara Lubich, włoska nauczycielka ${ }^{1}$, założycielka Ruchu Focolari ${ }^{2}$, znana w różnych dziedzinach kultury, poświęciła swoje życie formacji młodych pokoleń. Jej zdaniem wychowanie powinno koncentrować się na tym, co nazywa ona „celem wychowawczym”, „najwyższym celem”: „Aby wszyscy byli jedno”. Jest on uważany za „cel najważniejszy”, ponieważ jego osiągnięcie oznacza „stawanie się jako jednostki i jako wspólnoty zdolnymi do współpracy, spotkania, dialogu, służby"' . Z tak sformułowanego celu wynika fundamentalne dla wychowania znaczenie relacji. Jej podejście można by zdefiniować jako wychowanie interpersonalne, zawsze otwarte na najszerszą społeczną i globalną wzajemność, która odnajduje swoją istotę w relacji.

Tworzenie tożsamości relacyjnej wymaga zbieżności dwóch komponentów: autonomii i otwartości na drugą osobę, inną ode mnie, oraz rozwoju własnych potencjałów tożsamości i umiejętności dialogu z innymi, różniącymi się ode mnie. Ten proces formacji osoby jest głównym celem wychowania na wszystkich poziomach. Cel, jaki zawsze stawiano wychowaniu (kształtowaniu człowieka, jego autonomii), osiągany jest prawie paradoksalnie poprzez kształtowanie człowieka-relacji ${ }^{4}$. Lubich, w ramach wykładu z okazji otrzymania doktoratu honoris causa z psychologii, stwierdza, że poczucie własnej tożsamości jest niemożliwe do osiągnięcia przez pojedynczego człowieka, jeśli brak mu drugich, którzy uznają go jako podmiot ${ }^{5}$.

Może pojawić się pytanie: czy są to tylko stwierdzenia autorytatywnej i wybitnej przedstawicielki współczesnej duchowości, niepoparte dowodami

${ }^{1}$ Por. Franco de Battaglia, „La Maestra Silvia negli anni di scuola 1939-1943”, w: Essere educatori. Coraggio di una presenza, red. Michele De Beni (Roma: Citta Nuova, 2013), 17-27.

${ }^{2}$ Por. Armando Torno, Chiara Lubich. Życie i dzieło (Poznań-Warszawa: Fundacja Mariapoli, Wyd. Święty Wojciech, 2013).

3 Chiara Lubich, „Charyzmat jedności i pedagogika”, w: Chiara Lubich, Charyzmat jedności, red. Michele Vandeleene (Kraków: Fundacja Mariapoli i Wydawnictwo M, 2007), 320.

4 Tamże, 319.

${ }^{5}$ Chiara Lubich, „Charyzmat jedności i psychologia”, w: Chiara Lubich, Charyzmat jedności, red. Michele Vandeleene (Kraków: Fundacja Mariapoli i Wydawnictwo M, 2007), 325. 
naukowymi i dalekie od rzeczywistości? Czy też są to idee osadzone naukowo, w szczególności w dziedzinie neuronauk i psychologii?

W tym artykule spróbujemy wykazać, czy istnieje taka korelacja, a konkretnie, czy istnieje związek między rozwojem umysłowym, uczeniem się i relacyjnością.

\section{Mózg jako organ społeczny}

Ludzki mózg jest organem społecznym. Tak jak ludzie pozostają w relacji do innych, także mózg pozostaje $\mathrm{w}$ relacji z innymi mózgami ${ }^{6}$. Jako ludzie ewoluowaliśmy, aby istnieć jako istoty społeczne. Procesy mentalne są wytworem naszych wewnętrznych połączeń nerwowych i naszej komunikacji międzyludzkiej w połączeniu z innymi ludźmi

Charles Taylor pokazuje cechy natury ludzkiej o jej wyraźnie dialogowym charakterze. Proces, w którym tworzy się tożsamość osobowa, nigdy nie może być opisywany w terminach ,monologicznych”. W rzeczywistości język, jako organ warunkujący bycie człowiekiem, wymaga ciągłej wymiany z drugim ${ }^{8}$. W odniesieniu do tego Stephen A. Mitchell stwierdza: „Umysł składa się z konfiguracji relacyjnych; jednostkę można zrozumieć tylko na tle jej przeszłych i obecnych relacji"".

Jeśli poszczególne neurony nie pozostają w relacji z innymi neuronami, to więdną, umierają i giną. Podobny proces obserwuje się u ludzi. Jeśli nie połączymy się lub nie będziemy mieć relacji z innymi, zaczniemy „zanikać”10. Komunikacja bezpośrednio kształtuje mózg rozwijającego się dziecka. Według Daniela Siegela „umysł powstaje w wyniku procesów neurofizjologicznych zachodzących w substancji mózgowej oraz procesów, które wyłania-

${ }^{6}$ Luis Cozolino, Susan Sprokay, „Neuroscience and Adult Learning”, New Directions for Adult and Continuing Education 2 (2006): 11-19.

17 Daniel J. Siegel, The developing mind: Toward a neurobiology of interpersonal experience (New York: Guilford, 1999).

${ }^{8}$ Charles Taylor, „La politica del riconoscimento”, w: Jürgen Habermas, Charles Taylor, Multiculturalismo. Lotte per il riconoscimento (Milano: Feltrinelli, 1998), 9-62.

9 Stephen A. Mitchell, Gli orientamenti relazionali in psicoanalisi (Torino: Bollati Boringhieri, 1993), 5.

${ }^{10}$ Daniel J. Siegel, „Toward an interpersonal neurobiology of the developing mind: attachment relationships, 'mindsight,' and neural integration, UCLA School of Medicine", Infant Mental Health Journal 1-2 (2001): 67-94. 
ją się z relacji międzyludzkich". Pojęcia te dla wychowawców są niezbędne, ponieważ mogą pomóc $\mathrm{w}$ integralnym rozwoju dzieci ${ }^{11}$.

Doświadczenia relacyjne mają bardzo znaczący wpływ na mózg. W rzeczywistości obwody odpowiedzialne za percepcję społeczną są powiązane z obwodami kontrolującymi tworzenie znaczenia. Doświadczenie interpersonalne ma rolę organizacyjną w określaniu rozwoju struktury mózgowej we wczesnych etapach życia oraz w funkcjonowaniu mózgu przez całe życie ${ }^{12}$. Doświadczenie aktywuje neurony i kształtuje strukturę mózgu, która zmienia się nieprzerwanie przez całe życie. Aktywuje ono także geny syntetyzujące białka, zdolne do modelowania struktury mózgu ${ }^{13}$.

\section{Plastyczność mózgu}

Ostatnie odkrycia neuronauk sugerują, że mózg jest plastyczny, tzn. otwarty na ciągłe wpływy pochodzące $\mathrm{z}$ otoczenia ${ }^{14}$. Ta plastyczność może dotyczyć nie tylko tworzenia się nowych połączeń synaptycznych między neuronami, ale także powstawania nowych neuronów w ciągu całego życia ${ }^{15}$.

Niektóre badania pokazują, w jaki sposób mogą zachodzić zmiany w mózgu, jak doświadczenie mentalne (obraz) może zmieniać fizyczną strukturę mózgu (połączenia synaptyczne). Ta neuroplastyczność powoduje, że wewnętrzna świadomość, wytworzona przez samogenerujący się obraz, może pogorszyć aktywność połączeń nerwowych w określonych obszarach mózgu ${ }^{16}$.

Dopasowanie się do siebie nauczyciela i ucznia polega na stworzeniu zmiany w mózgu, dzięki czemu może on przyjmować nowe informacje. Ten fakt został udowodniony w trakcie różnych badań, które wykazały, że opieka

11 Siegel, The developing.

12 Tamże.

${ }^{13}$ Eric R. Kandel, „A New Intellectual Framework for Psychiatry”, American Journal of Psychiatry 155 (4) (1998): 457-469; Charles Aleksander Nelson, Floyd E. Bloom, „Child Development and Neuroscience”, Child Development 68 (5) (1997): 970-987; Siegel, „Toward an interpersonal".

${ }^{14}$ Helen Barbas, „Anatomic basis of cognitive-emotional interactions in the primate prefrontal cortex", Neuroscience and Biobehavioral Reviews 19 (1995): 499-510; Francine M. Benes, „Human brain growth spans decades”, American Journal of Psychiatry 155 (1998): 1489.

15 Siegel, „Toward an interpersonal”.

16 Siegel, The developing. 
i wsparcie nauczyciela wraz z jego zdolnością do dowartościowania ucznia są w stanie spowodować znaczące zmiany mózgowe ${ }^{17}$. Rozwój mózgu staje się w ten sposób procesem dynamicznym, podlegającym ciągłej reorganizacji w całym cyklu życia ${ }^{18}$.

\section{Neurobiologia interpersonalna}

Neurobiologia interpersonalna jest to podejście, które ma na celu połączenie aspektów neurobiologicznych, subiektywnych doświadczeń i relacji międzyludzkich. Siegel na podstawie swojej teorii umysłu mówi o neurobiologii interpersonalnej. Według niego umysł wyłania się z mózgu w takim stopniu, w jakim jest on modelowany i zmieniany przez relacje międzyludzkie. Siegel podkreśla, że ,umysł powstaje z przepływu informacji i energii do wnętrza samego mózgu i pomiędzy dwoma lub więcej mózgami"19.

Interakcje emocjonalne $\mathrm{z}$ osobami, z którymi istnieje więź uczuciowa, są bardzo ważne we wczesnym dzieciństwie, ponieważ pomagają rozwinąć poczucie samoświadomości. Umysł rozwija się w interakcji z innym znaczącym umysłem, a stany mentalne innych osób są reprezentowane w mózgu poprzez działanie neuronowe ${ }^{20}$. W wyniku tej interakcji z „obiektem” powstają w mózgu dziecka mapy neuronowe samego siebie. Te mapy neuronowe są istotą tego, w jaki sposób mózg tworzy obrazy własnego umysłu lub innych umysłów (postawy, przekonania, myśli itp.), w pewnym reprezentatywnym procesie zwanym psychowzrocznością (mindsight) ${ }^{21}$. Ta złożona zdolność rozwija się w dzieciństwie i może ubogacać się przez całe życie ${ }^{22}$. Przykład tego można znaleźć w relacji między matką a dzieckiem, gdy we wzajemnych interakcjach dziecko i matka uśmiechają się do siebie wzajem-

17 Cozolino, Sprokay, „Neuroscience”.

18 Beatriz Rodriguez Vega, Alberto Fernández Liria, Carmen Bayón Pérez, „Neurobiología interpersonal”, w: Manual de Psiquiatría, red. Tomás Palomo, Miguel Ángel Jiménez-Arriero (Madrid: Ene Life Publicidad, 2000), 3-8.

19 Daniel J. Siegel, ,An Interpersonal Neurobiology Approach to Psychotherapy”, Psychiatric Annals 36 (2006): 4.

${ }^{20}$ Valerie Stone, Simon Baron-Cohen, Robert T. Knight, „Frontal lobe contributions to theory of mind", Journal of Cognitive Neuroscience 10 (1998): 640-656.

${ }^{21}$ Kenneth Aitken, Colwyn Trevarthen, ,Self-other organization in human psychological development", Development and Psychopathology 9 (1997): 653-678.

${ }^{22}$ Siegel, „Toward an interpersonal”. 
nie. W tym doświadczeniu pojawiają się narastające emocje, które stymulują procesy metaboliczne w mózgu, umożliwiając większy wzrost i rozwój, nie tylko w mózgu, ale w całym ciele.

Inaczej dzieje się u dzieci porzuconych i zaniedbanych. W rzeczywistości ich rozwój mózgu i wzrost ciała zmniejszają się ${ }^{23}$. Sytuacje stresu, które powstają w szkole lub w środowisku wychowawczym, lub negatywne wspomnienia z przeszłych doświadczeń mogą osłabić lub zablokować proces uczenia się. Natomiast jeśli nauczyciel prezentuje postawę troski i zachęty, powstaje korzystny stan biologiczny, powodowany wydzielaniem się w mózgu ucznia neuropeptydów, co czyni go zdolnym do uczenia się i przyjmowania nowych informacji.

\section{Teoria umyslu}

$\mathrm{Z}$ tego, co przedstawiono dotychczas, wynika, że w relacjach międzyludzkich umysł i mózg są połączone ze sobą przepływami energii, które otrzymują i przekazują informacje. Za Siegelem możemy powiedzieć, że umysł ,powstaje w interakcji między neurofizjologią i międzyosobowością, kiedy mózgi wchodzą ze sobą w interakcje"24.

Niektóre badania z obszaru neuronauk pomagają nam zrozumieć, w jaki sposób relacje interpersonalne wpływają na rozwój mózgu. Byłoby niezwykle interesujące poznanie mechanizmów, dzięki którym działanie mózgu wpływa na intersubiektywność. Zaproponowana przez Davida Premacka i Gu Woodruffa w 1978 r. Teoria umystu $u^{25}$ wyjaśnia tę zdolność poznawczą jednostek do przypisywania stanów mentalnych innym i sobie. Termin ten odnosi się do umiejętności rozumienia i przewidywania zachowania innych, ich emocji i intencji. Teoria umysłu pomaga także zrozumieć oszustwo i kłamstwo, a następnie pomaga jednostce kłamać i oszukiwać ${ }^{26}$. Jako ludzie w rzeczywistości jesteśmy obdarzeni wrodzoną zdolnością, która pozwala

${ }^{23}$ Ruth Buczynski, Louis Cozolino, ,The Neuroscience of Psychotherapy” (2011), www. nicabm.com (A Teleseminar Session with Louis Cozolino, PhD and Ruth Buczynski, PhD).

${ }^{24}$ Siegel, „An Interpersonal”, 4.

${ }^{25}$ David Premack, Gu Woodruff, „Does the Chimpanzee have a Theory of Mind?”, Brain and Behavioral Sciences 1 (1978): 515-526.

${ }^{26}$ Uribe D. S. Ortiz, Gómez M. Botero, Arango O. E. Tobón, „Teoría de la mente: una revisión acerca del desarrollo del concepto", Revista Colombiana de Ciencias Sociales 1 (2010): $28-37$. 
nam być w relacji. Możemy komunikować się, przekazując nasze pragnienia, a z drugiej strony możemy rozumieć przekonania i intencje innych ${ }^{27}$.

W ewolucji teorii umysłu znajduje się pewien ważny punkt zwrotny dzięki badaniom przeprowadzonym przez Simona Barona-Cohena, Alana Lesliego i Utę Frith ${ }^{28}$. Autorzy ci stwierdzili, że u osób z autyzmem nie można odwoływać się do ToM (teorii umysłu) z powodu ich niezdolności do przypisywania stanów psychicznych sobie i innym, nie są one w stanie przewidzieć i wytłumaczyć zachowań. Hipoteza ta została oparta częściowo na pracach Alana Lesliego, autora analizy zdolności poznawczych u normalnych dzieci, i ma na celu zrozumienie gry fikcji. Według Lesliego i Frith dzieci od pierwszego roku życia rozwijają umiejętność opracowywania reprezentacji na reprezentacjach (meta-reprezentacji) wydarzeń w świecie rzeczywistym ${ }^{29}$.

To, że dzieci w wieku od 12 do 24 miesięcy rozumieją zamierzone działania, zostało już wykazane w różnych badaniach opublikowanych w ostatnich dekadach. Dzieci w wieku powyżej 14 miesięcy mogą spontanicznie zaoferować swoją pomoc osobie, która próbuje wykonać zadanie, ale nie realizują tego zgodnie z jej zamiarem ${ }^{30}$. Natomiast powyżej 12 miesiąca życia są one w stanie pomóc „nieświadomemu” eksperymentatorowi ${ }^{31}$. Badania te pokazują, że istnieje już wspólna intencjonalność u dzieci w tym wieku i dla niektórych autorów przemawia to za uznaniem ToM u ludzi ${ }^{32}$.

Teoria umysłu jest zatem kluczowym elementem do zrozumienia komunikacji interpersonalnej w procesach nauczania-uczenia się. W relacjach interpersonalnych nieustannie interpretujemy zachowanie drugiego, przyjmując jego stany mentalne jako idee, przekonania, pragnienia, intencje, zainteresowania. Interpretujemy czyjeś zachowanie jako wynik pewnych jego

27 Vittorio Gallese, „Neuroscienze e fenomenologia”, http://old.unipr.it/arpa/mirror/pubs/ pdffiles/Gallese, Neuroscienze_e_fenomenologia_finale.pdf [dostęp: 14.04.2018].

${ }^{28}$ Simon Baron-Cohen, Alan Leslie, Uta Frith, ,Does the autistic child have a 'theory of mind'?", Cognition 21 (1985): 37-46.

29 Alan Leslie, Uta Frith, „Autistic children's understanding of seeing, knowing and believing”, British Journal of Developmental Psychology 6 (1988): 315-324.

${ }^{30}$ Felix Warneken, Michael Tomasello, ,Altruistic Helping in Human Infants and Young Chimpanzees", Science 31 (2006): 1301-1303.

${ }^{31}$ Ulf Liszkowski, Malinda Carpenter, Michael Tomasello, „Twelve-Month-Old communicate Helpfully and Appropriately for Knowledgeable and Ignorant Partners", Cognition 108 (2008): 732-739.

${ }^{32}$ Michael Tomasello, The Cultural Origins of Human Cognition (Cambridge, Mass.: Harvard University Press, 1999); Michael Tomasello, Why We Cooperate (Massachusetts: MIT Press., 2009). 
myśli, uczuć lub pragnieńn ${ }^{33}$. Ten system wiedzy pozwala wywnioskować, jakie są czyjeś pragnienia i uczucia, oraz je zinterpretować.

$\mathrm{Z}$ tego, co powiedzieliśmy do tej pory, rozumie się, że promocja ToM w szkole przynosi korzyści w nauce szkolnej. Jerome Bruner ${ }^{34}$ stwierdza, że dobra ToM pomaga dzieciom uczyć się refleksji nad własnymi procesami myślenia. Oznacza to, że metapoznawcze umiejętności uzyskują ci, którzy pomagają w uczeniu się. Później wykazano, że w latach przedszkolnych istnieje pozytywna relacja pomiędzy poziomem ToM a umiejętnościami metapoznawczymi w szkole podstawowej ${ }^{35}$. Ta ludzka umiejętność okazuje się zatem podstawowa zarówno dla kulturowego uczenia się, jak i dla relacji międzyludzkich. Nauczanie polega na przekazywaniu czegoś, dlatego zarówno nauczyciel, jak i uczeń muszą rozumieć wzajemnie swoje umysły, wnioskować o swojej wiedzy i zainteresowaniach ${ }^{36}$.

\section{Neurony lustrzane}

Innego ważnego odkrycia, potwierdzającego tę teorię, dokonał w Parmie w 1995 r. zespół włoskich neurobiologów pod kierunkiem Giacomo Rizzolatiego, badając małpy wyszkolone w chwytaniu przedmiotów. Dzięki mikroelektrodzie wszczepionej w korze przedruchowej (gdzie są planowane i uruchamiane ruchy), rejestrowano elektryczną aktywność niektórych neuronów. W pewnym momencie rejestrujące urządzenie zostało aktywowane przy braku jakiejkolwiek aktywności ze strony badanej małpy. Zauważono wówczas, że inna małpa wykonuje podobne działanie. Naukowcy odkryli w ten sposób pewien rodzaj nieznanych do tej pory neuronów, zwanych neu-

33 Angel Rivière, Objetos con mente (Madrid: Alianza, 1991); Angel Rivière, Maria Núñez, La mirada mental (Buenos Aires: Aique, 1997); Andrew Whiten, Natural Theories of Mind (Oxford: Blackwell, 1991); Juan C. Gómez, El desarrollo de la mente en los simios, los monos y los niños (Madrid: Morata, 2007); Emilio G. García, Mente y cerebro (Madrid: Síntesis, 2001); Emilio G. García et al., Nuevas perspectivas cientificas y filosóficas sobre el ser Humano (Madrid: Universidad Comillas, 2007).

34 Jerome Bruner, The Culture of Education (Cambridge, Mass.: Harvard University Press, 1996).

35 Wolfgang Schneider, „The Development of Metacognitive Knowledge in Children and Adolescents: Major Trends and Implications for Education", Mind Brain and Education 2 (2008): 114.

36 Emilio G. García, „Neuropsicologia y educación. De las neuronas espejo a la teoría de la mente", Rev. de psicologia y educación 3 (2008): 69-90. 
ronami lustrzanymi. Te neurony reagują, gdy działanie i jego cel są postrzegane razem, a nie uaktywniają się, gdy obiekty są łączone bez celu. Oznacza to, że komórki reprezentują cel w połączeniu z ruchem ${ }^{37}$.

Neurony lustrzane są aktywowane także w procesie pedagogicznym. Mózg dziecka, które widzi działanie swojego nauczyciela, symuluje mentalnie w postaci synchronicznej działania prezentowane przez nauczyciela i jednocześnie je interpretuje. Dzięki swojej neurofizjologii dziecko dedukuje intencje nauczyciela i w ten sposób przyswaja pojęcia i procesy, z którymi współdziała na poziomie mózgowym i społecznym.

W niektórych badaniach występuje korelacja empatii i sympatii z funkcjonowaniem tej konkretnej części mózgu, w której mieści się system neuronów lustrzanych. Według autorów tego odkrycia można sformułować wniosek, że neurony lustrzane są podstawą intersubiektywności i empatii ${ }^{38}$. W pewnym sensie ,zrealizowana symulacja może być uważana za funkcjonalny korelat empatii" ${ }^{39}$. Natomiast według Barona-Cohena należy wziąć pod uwagę także inne czynniki, które leżą u podstaw obwodu empatii i które nie mają wyłącznie charakteru organicznego. Obwód empatii np. może zostać zaburzony przez pewne doświadczenia z wczesnych lat życia, w których dziecko nie doświadczyło wsparcia uczuciowego lub gdy doświadczyło różnych form przemocy albo nadużyć. Jednakże zdolność empatyczna - chociaż zredukowana przez różne wydarzenia traumatyczne - może się poprawić, ilekroć tylko ktoś stara się zrozumieć myśli i uczucia innych.

Na podstawie funkcjonalnego rezonansu magnetycznego (FMRI) autor ten wykazuje, że poziom empatii zależy od „obwodu empatycznego”, którego obszary w mózgu zostały uszkodzone w przypadkach pogranicznego zaburzenia osobowości (borderline) oraz u psychopatów. W tych przypadkach pojawi się niemożność zrozumienia konsekwencji swoich działań. Tak więc empatia wykracza poza automatyczne odzwierciedlanie, stanowiące możliwość zrozumienia stanów psychicznych innych osób poprzez aktywację specyficznego neuronalnego obwodu empatii ${ }^{40}$. Mechanizmy symulacji po-

37 Tamże.

38 Vittorio Gallese, „Dai neuroni specchio alla consonanza intenzionale. Meccanismi neurofisiologici dell'intersoggettività", Rivista di Psicoanalisi 1 (2007): 197-208; Giacomo Rizzolatti, „Neuroni specchio ed empatia”, intervento del 22 settembre 2012 a „Pordenone legge", http://www.youtube.com/watch?v=02szjHTch98 [dostęp: 19.06.2018].

39 Gallese, „Dai neuroni”, 197-208.

40 Simon Baron-Cohen, La scienza del male. L'empatia e le origini della crudeltá (Milano: Raffaelo Cortina, 2012). 
zwalają nam umieć rozdzielić na płaszczyźnie empirycznej stany mentalne innych. Seria nowych badań zdaje się potwierdzać hipotezę, że w autyzmie dziecięcym różne z tych mechanizmów wydają się zafałszowane.

Wracając do neuronów lustrzanych: są one w stanie uaktywniać się nawet wtedy, gdy obserwacja nie jest całkowicie widoczna. Na przykład jeśli nie widać interakcji między ręką, ramieniem lub stopą a przedmiotem, można ją ,wywnioskować”, przyglądając się, obserwując obiekt ${ }^{41}$. W tym przypadku nie mówi się jednak o wnioskowaniu logicznym, ale o wyniku symulacji motorycznej. Aktywacja programu motorycznego z pozycji obserwatora odpowiada pewnemu działaniu, którego nie można zobaczyć w całości. Ale - postrzegane nawet tylko częściowo - pozwala na zrozumienie. Liczne badania wykazały, że podobny mechanizm odzwierciedlania występuje również w mózgu ludzkim i jest oparty na specyficznej zgodności, punkt po punkcie, pewnej części ciała z określonym obszarem centralnego systemu nerwowego. Kiedy obserwujemy działania wykonywane przez innych za pomocą ust, dłoni czy stopy, aktywujemy odpowiednie obszary naszego układu motorycznego ${ }^{42}$.

Dzięki kluczowym mechanizmom tworzenia kopii lustrzanych i symulacji zrozumieliśmy intersubiektywność, w której drugi jest doświadczany jako „inne ja”. Domyślnie przypisujemy drugiemu status innej podmiotowości, która dzieli z nami ludzką kondycję, i dlatego możemy odnosić się do niej z pełną wzajemnością. Faktycznie, te mechanizmy neuronalne nie są uaktywniane tylko w domenie działania, ale także w zakresie emocji lub wrażeń. Intersubiektywność przekształca się zatem w ontologiczny fundament życia ${ }^{43}$.

\section{Od empatii do prospołeczności, od prospołeczności do sztuki miłowania według Chiary Lubich}

Empatia to pewien stan poznawczy i emocjonalny, który ułatwia jakość relacji międzyludzkich. Dla Martina L. Hoffmana fakt współczucia, rozumianego jako dzielenie emocji z tymi, którzy cierpią, jest motywacją do pod-

${ }^{41}$ Maria A. Umiltà et al., "'I know what you are doing': a neurophysiological study”, Neuron 32 (2001): 91-101; Warneken, Tomasello, „Altruistic Helping”, 1301-1303.

${ }^{42}$ Gallese, „Dai neuroni”, 197-208.

${ }^{43}$ Tamże. 
jęcia pomocy ${ }^{44}$. Pojawia się zatem związek między empatią a prospołecznością. Przez zachowania prospołeczne rozumie się:

te zachowania, które bez oczekiwania na wynagrodzenie z zewnątrz (materialne lub niematerialne) wspomagają innych ludzi lub grupy, zgodnie $z$ ich kryteriami lub z celami społecznymi, obiektywnie pozytywnymi, które zwiększają prawdopodobieństwo wystąpienia pozytywnej i wyjątkowej wzajemności oraz solidarności w stosunkach międzyludzkich lub konsekwencji społecznych, ochrony tożsamości, kreatywności i inicjatywy zaangażowanych osób lub grup $^{45}$.

Związek między empatią a prospołecznością jest dwukierunkowy. Empatia ułatwia powrót aktów prospołecznych, a jednocześnie można powiedzieć, że ludzie, którzy działają prospołecznie, będą stopniowo uczyć się optymalizować swoją zdolność do empatii.

Według Hoffmana stopień empatii wiąże się z osądami moralnymi, tzn. $\mathrm{z}$ etycznymi postawami ludzi. Poznawcze zrozumienie myśli drugiego lub doświadczanie podobnych uczuć mogą promować postawy gotowości do pomocy drugiemu, a takie nastawienie jest motywowane zasadami i normami, stanowiącymi zbiór wartości, które kierują zachowaniem się ludzi.

W myśli i pismach Lubich znajduje się kategoria „sztuka miłowania”46, która wykazuje podobieństwo z empatią i prospołecznością: dotyczy to tzw. dyplomacji miłości lub ,jednoczenia się”, które Lubich opisuje następująco:

Jednoczyć się z bliźnim w takim całkowitym zapomnieniu o sobie, w jakim nawet tego nie zauważając i nie troszcząc się o to - żyje ten, kto myśli o drugim, o bliźnim. To jest „dyplomacja miłości”, która ma wiele cech i wyrazów zwykłej dyplomacji i dlatego nie mówi wszystkiego, co można by powiedzieć, bo bratu by się to nie podobało, a Bogu nie byłoby miłe. Umie czekać, umie mówić, umie osiągać cel [...]. Jest w niej jednak istotny i charakterystyczny odcień, odróżniający ją od dyplomacji w rozumieniu świata, gdzie słowo „dyplomatyczny" jest często synonimem ukrywania prawdy albo wręcz fałszu. Tym,

${ }^{44}$ Martin L. Hoffman, „Development of prosocial motivation: Empathy and guilt”, w: Thedevelopment of prosocial behavior, red. Nancy Eisenberg (New York: Academic Press, 1982), 282-313.

45 Roberto R. Olivar, Psicologia y Educacion para la Prosocialidad (Buenos Aires: Ed. Ciudad Nueva, 1996), 16.

${ }^{46}$ Por. Chiara Lubich, Arte di amare (Roma: Citta Nuova, 2005). 
co wielkie i swoiste dla dyplomacji Boskiej, co może tylko jej właściwe, jest to, że kieruje się dobrem drugiego, a więc jest wolna od najmniejszego cienia egoizmu ${ }^{47}$.

Sztuka miłowania - to zachowania ukierunkowane na dobro drugiego, pozbawione egoizmu, które dzięki swoim umiejętnościom empatycznym powodują pozytywną wzajemność - podobną do zachowań prospołecznych. Uczenie się takich zachowań może stanowić podstawę interpersonalnego wychowania, ponieważ prowadzi do dialogu, współpracy i jedności, chroniąc swoją tożsamość.

\section{Podsumowanie}

$\mathrm{Z}$ tego, co przedstawiono do tej pory oraz na podstawie badań w zakresie neuronauk, wynika kluczowe dla działań wychowawczych znaczenie uznania relacji z drugim za pewną przestrzeń, wewnątrz której „rodzi się” ludzki umysł i kształtują się podstawy naszej tożsamości. Ten drugi powinien być uznany, aby mógł się narodzić, wzrastać i dostąpić samorealizacji, która prowadzi do dobrego samopoczucia ${ }^{48}$.

Tym, co czyni możliwymi ludzkie relacje i rozwój tożsamości osobowej, jest możliwość uznania drugiego, innego ode mnie w jego specyficznej godności, obdarzając go zaufaniem, w empatycznym nastawieniu do umiejętności zrezygnowania $\mathrm{z}$ własnego punktu widzenia i własnych interesów ${ }^{49}$.

Odbywające się w relacji miłości wzajemne uznanie, pozwalając na utworzenie pełnej podmiotowości i zawsze nowej tożsamości, realizuje się poprzez dowartościowanie oraz szacunek. Natomiast relacja charakteryzująca się nonszalancją i aroganckim narzucaniem własnej woli prowadzi do nicości i niemożności wyjścia poza siebie samego ${ }^{50}$.

${ }^{47}$ Chiara Lubich, „Lud Boży”, w: Chiara Lubich, Charyzmat jedności, red. Michele Vandeleene (Kraków: Fundacja Mariapoli i Wydawnictwo M, 2007), 332.

48 Piero A. Cavaleri, Vivere con l'altro per una cultura della relazione (Roma: Città Nuova, 2007); Cozolino, Sprokay, „Neuroscience”.

${ }^{49}$ Cavaleri, Vivere; Pierpaolo Donati, „Il dono in famiglia e nelle altre sfere sociali”, w: Dono e perdono nelle relazioni familiari e sociali studi interdisciplinari sulla famiglia, red. Eugenia Scabini, Giovanna Rossi (Milano: Vita e pensiero, 2000), 55-132.

${ }^{50}$ Enrico Molinari, Piero A. Cavaleri, Il dono nel tempo della crisi. Per una psicologia del riconoscimento (Milano: Raffaello Cortina, 2015), 32-33; Paola Gaetano, „Dialettiche 
Z tego powodu wychowanie „do trudności” jako zadanie wciągające zarówno wychowanka, jak i wychowawcę jest kolejnym punktem kluczowym pedagogiki Chiary Lubich ${ }^{51}$.

Także na polu wychowania w przypadku różnych form nadopiekuńczości występuje - na wiele sposobów - tendencja, aby chronić dzieci przed jakimikolwiek trudnościami, przyzwyczajając je do postrzegania życia jako drogi ,zjazdowej”, łatwej i wygodnej. Faktycznie pozostawia się je wówczas w dużym zakłopotaniu wobec nieuniknionych prób życia, a w szczególności czyni się je biernymi i opornymi wobec odpowiedzialności, jaką każda istota ludzka powinna podejmować wobec samego siebie, wobec innych, wobec społeczeństwa. Wychowanie „do trudności” jest zadaniem, które angażuje zarówno wychowanka, jak i wychowawcę ${ }^{52}$.

W szczególności wychowywanie do umiejętności rozwiązywania sytuacji konfliktowych pozwala zmienić negatywne i frustrujące doświadczenie w sytuację, która odpowiednio przetransformowana, staje się okazją do osobistego dojrzewania i odkrycia drugiego ${ }^{53}$. Dzieje się tak, gdy „Ty” czuje się uznane i jest w stanie odwzajemnić ten dar z dowartościowaniem oraz wzajemnym szacunkiem. W ten sposób ten Drugi będzie mógł rozwinąć swoją prawdziwą tożsamość i wolność ${ }^{54}$.

Podsumowując, należy podkreślić, że stwierdzenia Chiary Lubich są mocno osadzone i znajdują odzwierciedlenie w różnych badaniach naukowych, dążących do pokazania, w jaki sposób relacje wzajemnego uznania inicjują organizację obwodów neuronalnych, zwiększając zdolności mózgu, a więc i uczenia się.

Ttumaczenie: Stanisław Grochmal

della reciprocità. Lo stile affettivo nelle organizzazioni di significato personale”, 2011, w: XIII convegno di psicologia e psicopatologia post-razionalista ,all you need is love": la rilevanza dello stile affettivo in psicoterapia post-razionalista (Atti del convegno a cura di Mario Antonio Reda e Luca Canestri).

${ }^{51}$ Chiara Lubich, „Charyzmat jedności a pedagogika”.

52 Tamże.

${ }^{53}$ Cavaleri, Vivere.

${ }^{54}$ Gaetano, „Dialettiche”. 


\section{Bibliografia}

Aitken, Kenneth; Colwyn Trevarthen. „Self-other organization in human psychological development". Development and Psychopathology 9 (1997): 653-678.

Barbas, Helen. „Anatomic basis of cognitive-emotional interactions in the primate prefrontal cortex". Neuroscience and Biobehavioral Reviews 19 (1995): 499-510 .

Baron-Cohen, Simon, Alan Leslie, Uta Frith. „Does the autistic child have a "theory of mind'?". Cognition 21 (1985): 37-46.

Baron-Cohen, Simon. La scienza del male. L'empatia e le origini della crudeltà. Milano: Raffaelo Cortina, 2012.

Battaglia, Franco de. „La Maestra Silvia negli anni di scuola 1939-1943”. W: Essere educatori. Coraggio di una presenza, red. Michele De Beni, 17-27. Roma: Città Nuova, 2013.

Benes, Francine M. „Human brain growth spans decades”. American Journal of Psychiatry 155 (1998): 1489.

Bruner, Jerome. The Culture of Education. Cambridge, Mass.: Harvard University Press, 1996.

Buczynski, Ruth, Louis Cozolino. „The Neuroscience of Psychotherapy” (2011). www.nicabm.com.

Cavaleri, Piero A. Vivere con l'altro per una cultura della relazione. Roma: Città Nuova, 2007.

Cozolino, Louis, Susan Sprokay. „Neuroscience and Adult Learning”. New Directions for Adult and Continuing Education 2 (2006): 11-19.

Donati, Pierpaolo. „Il dono in famiglia e nelle altre sfere sociali”. W: Dono e perdono nelle relazioni familiari e sociali studi interdisciplinari sulla famiglia, red. Eugenia Scabini, Giovanna Rossi. Milano: Vita e pensiero, 2000, 55-132.

Gaetano Paola. „Dialettiche della reciprocità. Lo stile affettivo nelle organizzazioni di significato personale", 2011. W: XIII convegno di psicologia e psicopatologia post-razionalista ,all you need is love": la rilevanza dello stile affettivo in psicoterapia post-razionalista (Atti del convegno a cura di Mario Antonio Reda e Luca Canestri).

Gallese, Vittorio. „Dai neuroni specchio alla consonanza intenzionale. Meccanismi neurofisiologici dell'intersoggettività'. Rivista di Psicoanalisi 1 (2007): 197_ -208 .

Gallese, Vittorio. „Neuroscienze e fenomenologia”. http://old.unipr.it/arpa/mirror/ pubs/pdffiles/Gallese,Neuroscienze_e_fenomenologia_finale.pdf [dostęp: 14.04. 2018]. 
García, Emilio G. Mente y cerebro. Madrid: Síntesis, 2001.

García, Emillio G. et al. Nuevas perspectivas cientificas y filosóficas sobre el ser Humano. Madrid: Universidad Comillas, 2007.

García, Emilio G. „Neuropsicologia y educación. De las neuronas espejo a la teoría de la mente". Rev. de psicologia y educación 3 (2008): 69-90.

Gómez, Juan C. El desarrollo de la mente en los simios, los monos y los niños. Madrid: Morata, 2007.

Hoffman, Martin L. ,Development of prosocial motivation: Empathy and guilt”. W: The development of prosocial behavior, red. Nancy Eisenberg, 282-313. New York: Academic Press, 1982.

Kandel, Eric R. „A New Intellectual Framework for Psychiatry”. American Journal of Psychiatry 155 (4) (1998): 457-469.

Leslie, Alan, Uta Frith. „Autistic children's understanding of seeing, knowing and believing”. British Journal of Developmental Psychology 6 (1988): 315-324.

Liszkowski, Ulf, Malinda Carpenter, Michael Tomasello. ,Twelve-Month-Old communicate Helpfully and Appropriately for Knowledgeable and Ignorant Partners". Cognition 108 (2008): 732-739.

Lubich, Chiara. Arte di amare. Roma: Città Nuova, 2005.

Lubich, Chiara. „Charyzmat jedności i pedagogika”. W: Chiara Lubich, Charyzmat jedności, red. Michele Vandeleene, 313-320. Kraków: Fundacja Mariapoli i Wydawnictwo M, 2007.

Lubich, Chiara. „Charyzmat jedności i psychologia”. W: Chiara Lubich, Charyzmat jedności, red. Michele Vandeleene, 322-326. Kraków: Fundacja Mariapoli i Wydawnictwo M, 2007.

Lubich, Chiara. „Lud Boży”. W: Chiara Lubich, Charyzmat jedności, red. Michele Vandeleene, 327-333. Kraków: Fundacja Mariapoli i Wydawnictwo M, 2007.

Mitchell, Stephen A. Gli orientamenti relazionali in psicoanalisi. Torino: Bollati Boringhieri, 1993.

Molinari, Enrico, Piero A. Cavaleri. Il dono nel tempo della crisi. Per una psicologia del riconoscimento. Milano: Raffaello Cortina, 2015.

Nelson, Charles A., Floyd E. Bloom. „Child Development and Neuroscience”. Child Development 68 (5) (1997): 970-987.

Olivar, Roberto R. Psicologia y Educacion para la Prosocialidad. Buenos Aires: Ciudad Nueva, 1996.

Ortiz, Uribe D. S., Gómez M. Botero, Arango O. E. Tobón. „Teoría de la mente: una revisión acerca del desarrollo del concepto". Revista Colombiana de Ciencias Sociales 1 (2010): 28-37.

Premack, David, Gu Woodruff. „Does the Chimpanzee have a Theory of Mind?”. Brain and Behavioral Sciences 1 (1978): 515-526. 
Rivière, Angel. Objetos con mente. Madrid: Alianza, 1991.

Rivière, Angel, Maria Núñez. La mirada mental. Buenos Aires: Aique, 1997.

Rizzolatti, Giacomo. „Neuroni specchio ed empatia”, intervento del 22 settembre 2012 a „Pordenone legge”. http://www.youtube.com/watch?v=02szjHTch98 [dostęp: 19.06.2018].

Rodríguez Vega, Beatriz, Fernández Liria, Alberto Pérez, Carmen Bayón. „Neurobiología interpersonal”. W: Manual de Psiquiatría, red. Tomás Palomo, Miguel Ángel Jiménez-Arriero, 107-113. Madrid: Ene Life Publicidad, 2009.

Siegel, Daniel J. The developing mind: Toward a neurobiology of interpersonal experience. New York: Guilford, 1999.

Siegel, Daniel J. „Toward an interpersonal neurobiology of the developing mind: attachment relationships, 'mindsight,' and neural integration, UCLA School of Medicine”. Infant Mental Health Journal 1-2 (2001): 67-94.

Siegel, Daniel J. „An Interpersonal Neurobiology Approach to Psychotherapy”. Psychiatric Annals 36 (2006): 1-18.

Schneider, Wolfgang. „The Development of Metacognitive Knowledge in Children and Adolescents: Major Trends and Implications for Education". Mind Brain and Education 2 (2008): 114-121.

Stone, Valerie, Simon Baron-Cohen, Robert T. Knight. „Frontal lobe contributions to theory of mind". Journal of Cognitive Neuroscience 10 (1998): 640-656.

Taylor, Charles. „La politica del riconoscimento”. W: Jürgen Habermas, Charles Taylor, Multiculturalismo. Lotte per il riconoscimento, 9-62. Milano: Feltrinelli, 1998.

Tomasello, Michael. The Cultural Origins of Human Cognition. Cambridge, Mass.: Harvard University Press, 1999.

Tomasello, Michael. Why We Cooperate. Massachusetts: MIT Press., 2009.

Torno, Armando. Chiara Lubich. Życie i dzieło. Poznań-Warszawa: Fundacja Mariapoli, Wyd. Święty Wojciech, 2013.

Umiltà, Maria A. et al. „'I know what you are doing': a neurophysiological study”. Neuron 32 (2001): 91-101.

Warneken, Felix, Michael Tomasello. „Altruistic Helping in Human Infants and Young Chimpanzees". Science 31 (2006): 1301-1303.

Whiten, Andrew. Natural Theories of Mind. Oxford: Blackwell, 1991. 
